\title{
Fish Can Get Diseases Too
}

Infectious diseases are increasingly recognized as an important component of the ecology of fish in the wild. Many of the viral, bacterial, protozoan and fungal pathogens of fish that were initially discovered in captive fish have their origin among wild populations; however, the impact of disease among these free-ranging stocks has been difficult to study. At the WFRC, combinations of field and laboratory investigations, aided by the tools of molecular biology, have begun to provide information on the ecology of infectious diseases among natural populations of fish in both freshwater and marine ecosystems.

The following diseases or pathogens of free-ranging populations of finfish have been studied at the WFRC:

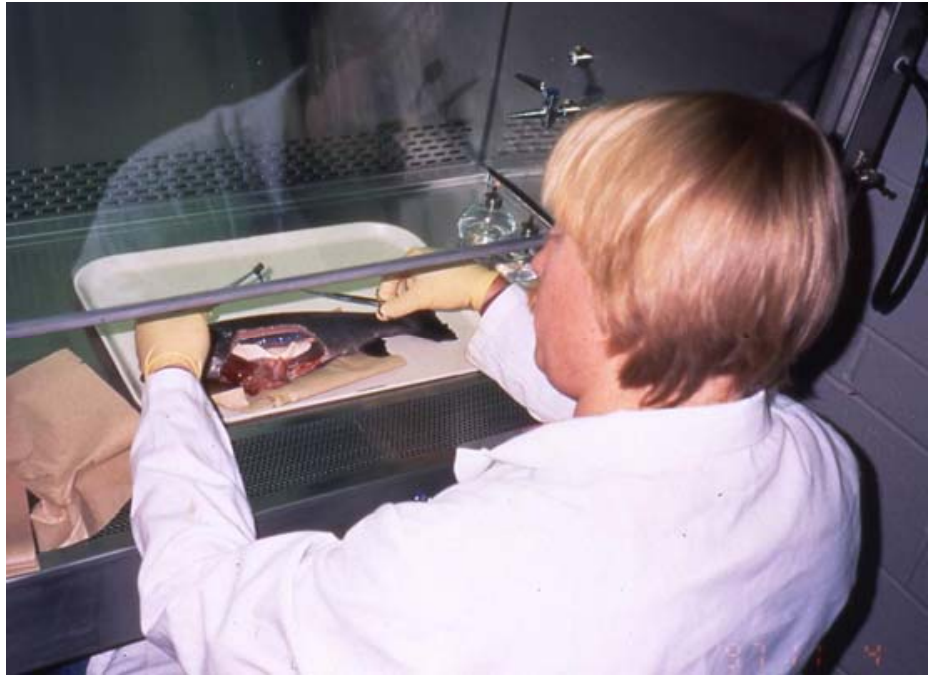

A researcher at the WFRC removes the anterior kidney from a rainbow trout at a sterile workstation. Cells from the anterior kidney are used to study various aspects of fish health including host/pathogen relationships, vaccine efficacy and the effects of hatchery rearing practices.
Bacterial kidney disease that affects the ability of juvenile Pacific salmon to migrate downstream and to survive in the ocean.

Infectious hematopoietic necrosis virus that can cause high losses among salmon fry.

Whirling disease that affects wild-spawning rainbow trout in the Rocky Mountain West.

Viral hemorrhagic septicemia in marine fishes of northern Puget Sound.

Ichthyophthirius and columnaris disease in returning adult salmon in the Klamath River.
Ceratomyxa and Parvacapsula infections of juvenile salmon in the Klamath River.

Ichthyophoniasis in adult chinook salmon in the Yukon River.

In addition, new studies, using state-of-the-art molecular biology techniques such as the polymerase chain reaction and cDNA microarrays, are aimed at

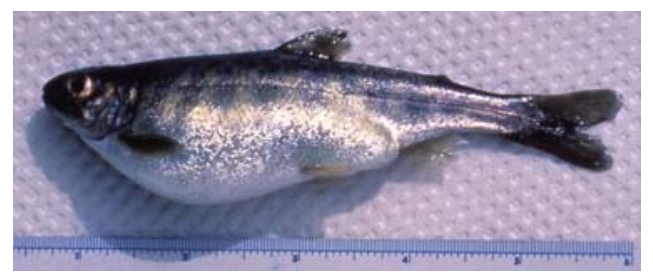

Juvenile Chinook salmon with bacterial kidney disease. trying to predict the influence of disease in the survival of juvenile salmonids exposed to various stressors during their outmigration.

\section{How are Bacterial Diseases Diagnosed in Fish?}

Bacterial and viral diseases can have a great negative impact on salmonid populations, especially in a hatchery setting. Some of these diseases kill many fish very quickly, others are slower to take hold but are also very deadly to fish. For these reasons, it is important to quickly identify any potential infection so that appropriate action can be taken to isolate, and often treat, the pathogen before an epizootic (an epidemic in animals) can occur. 


\section{Microscopic Slides of Bacteria}

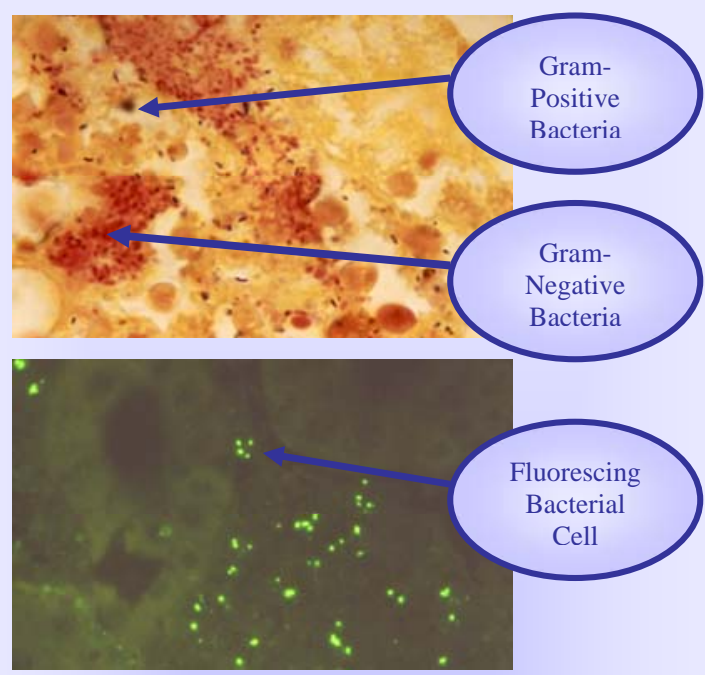

Gels
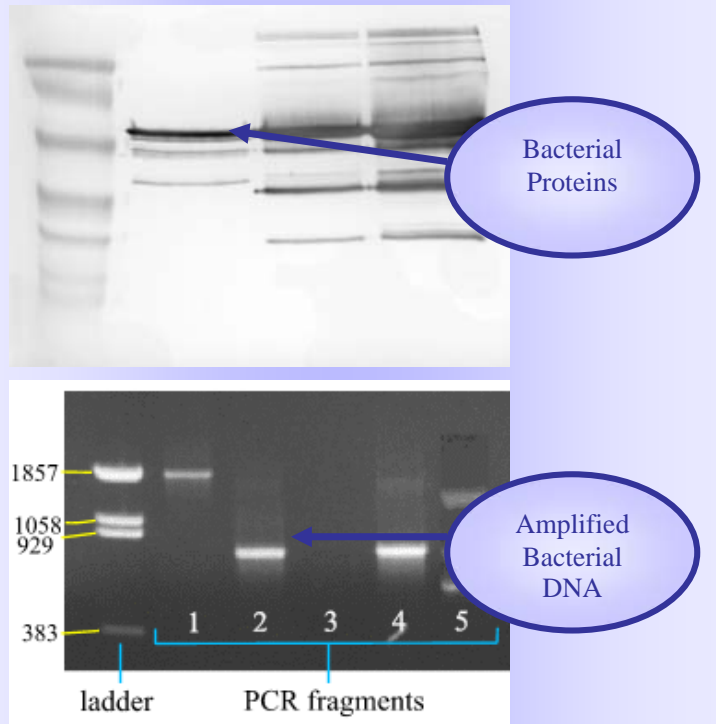

\section{Bacterial Culture Plates}

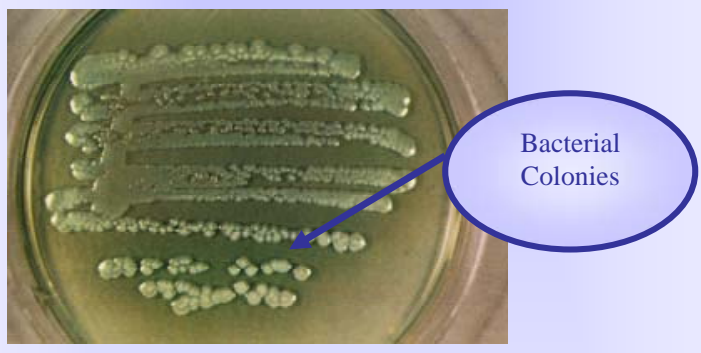

ELISA Assay

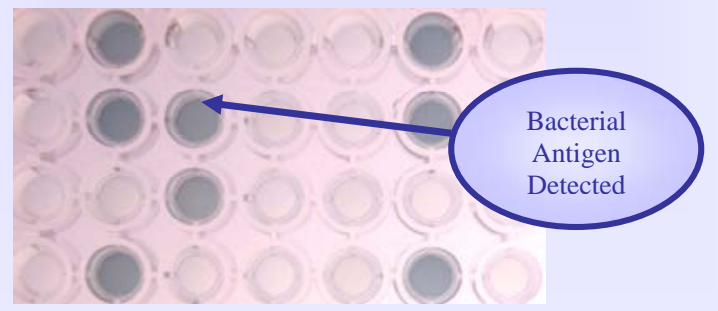

We use several diagnostic techniques to identify the presence of specific bacteria in salmonids. Some of these methods were developed in our laboratory and are now used for diagnosis of bacterial fish diseases in many parts of the world. (See sidebar)

\section{Salmonid Immune Function}

Anadromous salmonids are susceptible to a variety of disease causing (pathogenic) microorganisms, including at least 30 bacteria and viruses. Whereas the impact of these microorganisms on salmonids in wild and natural rearing areas is difficult to measure, losses from disease among hatchery salmonids are both common and well documented. The disease state depends on 3 factors, the host (fish), the disease organism, and the environment.

Disease is not the result of a single event, rather the consequence of an imbalance in the host-pathogen relationship. The presence of a pathogen in a salmon population will not always result in losses due to disease and fish can remain asymptomatic carriers under favorable conditions. However, stressors exceeding the limits of a fish's physiological tolerance will diminish its ability to resist disease, and consequently, become a threat to its health.

For salmon, the hatchery environment is quite different than the environments they inhabit in the wild. Successful fish husbandry

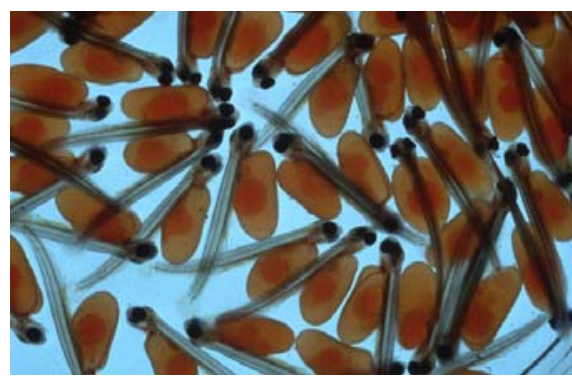

Young salmon fry may have been infected with the kidney disease bacterium before they hatched from the egg.

requires the minimization of environmental stressors such as handling, high rearing densities and poor water quality, while maintaining the carrying capacity of the facility. Unfortunately, there is no simple measure of the health status of a fish population. Since the immune system of any higher organism is essential for its well being, measures of the fishes defenses provide an attractive means to quantify fish health. However, we are only beginning to understand the immune system of salmon, and how it modulates with seasonal and life stage changes, or differing rearing conditions.

\section{Renibacterium salmoninarum}

\section{Renibacterium salmoninarum is} the causative agent of bacterial kidney disease (BKD), a serious disease problem of wild and
The kidney disease bacterium can be detected in fish tissues by the fluourescent antibody test.

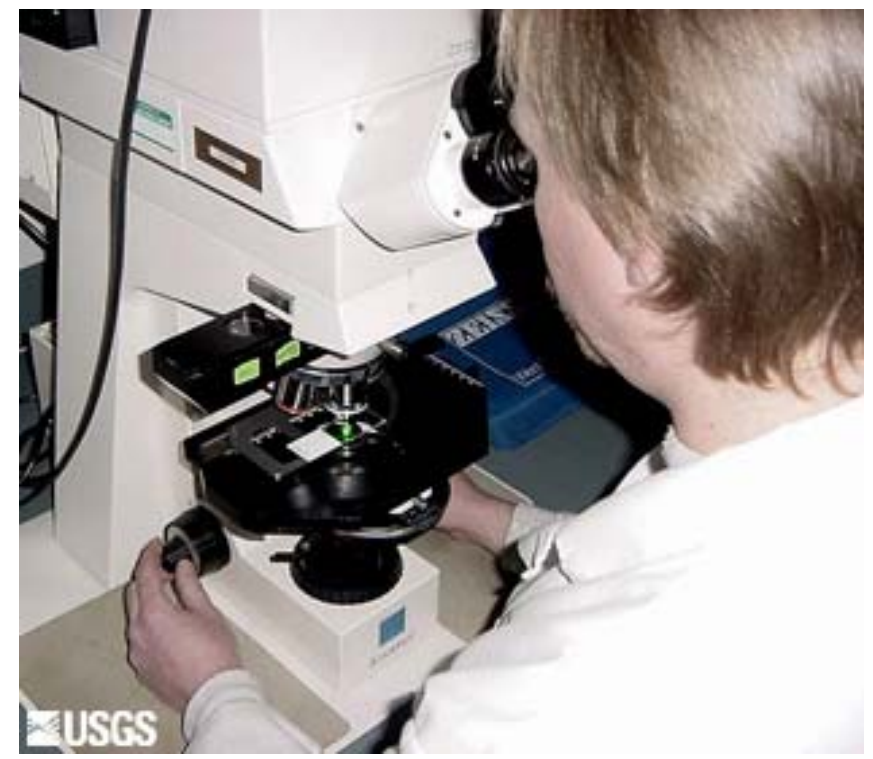


cultured salmonid fishes worldwide. Control of the bacteria by use of antibiotics is difficult due to its slow growth, and conventional vaccine strategies are ineffective or may actually worsen the disease state. Furthermore, the bacteria can be passed not only between fish in the same water system (horizontal transmission), but also from one generation to the next via infected eggs (vertical transmission). During infection, $R$. salmoninarum can evade immune surveillance by surviving and replicating within host macrophages (a type of white blood cell). Also, $R$. salmoninarum produces large amounts of a unique protein (p57) which suppresses a number of immune functions. Control of $R$. salmoninarum will require a better understanding of the bacteria itself, the salmonid immune system and how the bacteria and host defenses interact.

\section{Whirling Disease}

\section{Myxobolus cerebralis is a} metazoan parasite that penetrates the head and spinal cartilage of fingerling trout where it multiplies very rapidly, putting pressure on the organ of equilibrium. This causes the fish to swim erratically (whirl), and have difficulty feeding and avoiding predators. In severe infections, the disease can cause high rates of mortality in young-ofthe-year fish. Those that survive until the cartilage hardens to bone can live a normal life span, but are marred by skeletal deformities. Lightly infected fish can, however reproduce without passing on the parasite to their offspring.

Whirling disease has become a highly significant problem for fisheries managers in federal and state agencies throughout the nation. Thought to have been introduced from Europe, whirling disease was first detected in the U. S. in 1958 and has now been reported from fish in more than 20 states. The potential for whirling disease to cause losses in natural stocks of trout became a national concern in 1993-1994 when losses of up to $90 \%$ of the wild rainbow trout (Oncorhynchus mykiss) in

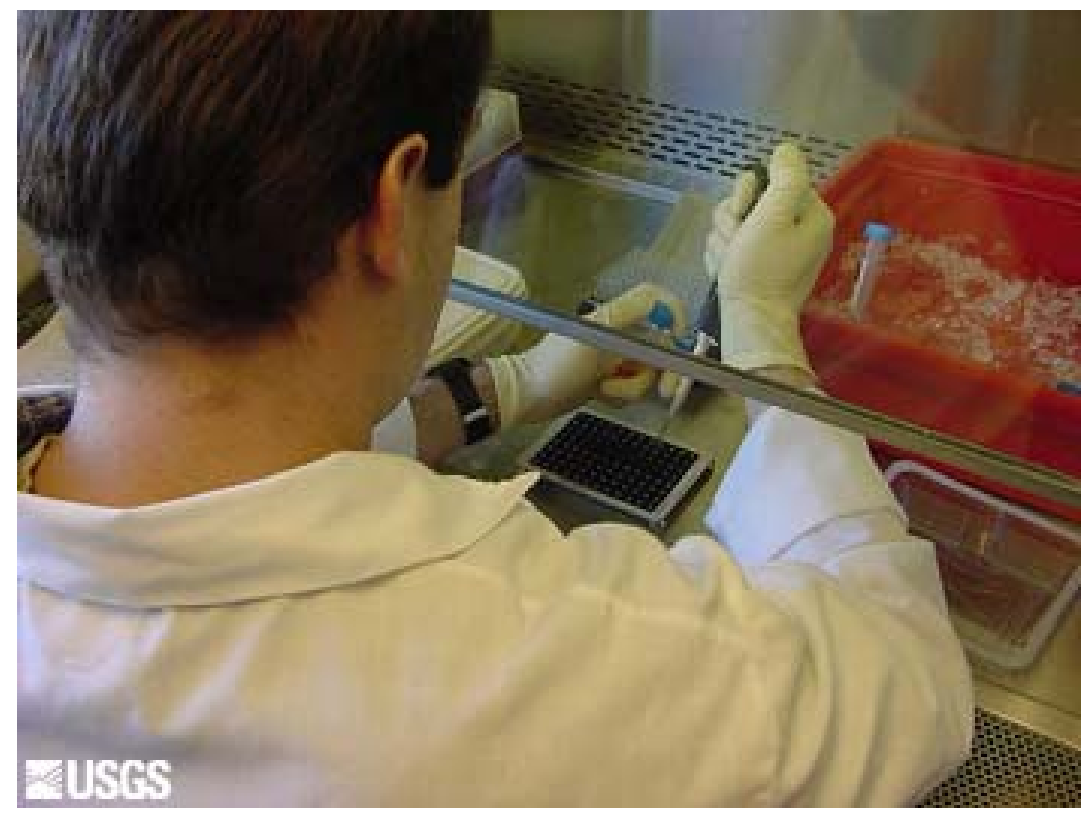

A toolbox of immunological assays is used to monitor the defenses of fish infected with the kidney disease bacterium. several trout streams in Colorado and Montana were attributed to whirling disease. Subsequently, a large, ongoing survey revealed that naturally spawning rainbow and brown trout in many western rivers were infected with the parasite with some of the fish showing clinical disease. Of additional concern was the presence of whirling disease in native stocks of cutthroat (Oncorhynchus clarki) and bull trout (Salvelinus confluentus) which are of special status due to their declining numbers. Improved diagnostic methods now provide epizootiological information about strains of the parasite or the alternate host.

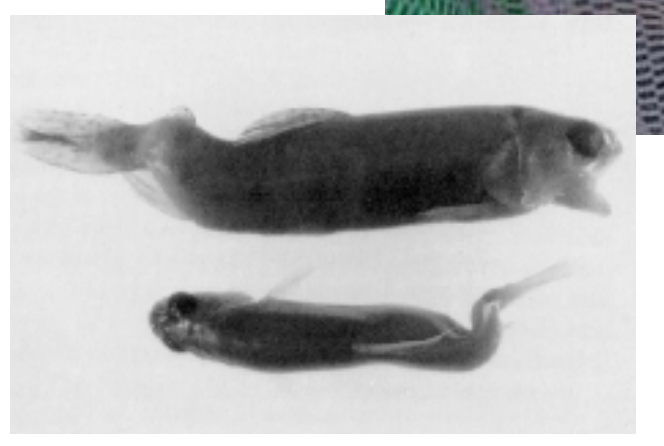

Deformed skeletons of 8-moonth old rainbow trout (Oncorhynchus mykiss) with whirling disease.

\section{IHN Virus}

Infectious haematopoietic necrosis (IHN) is an infectious viral disease of salmon and trout. It was first recognized in the 1950s in sockeye and chinook salmon. The disease has the most economic significance for freshwater farms, however Pacific and Atlantic salmon (Salmo salar L.) in both fresh and sea water have been severely affected. 
Fry and small fingerlings become infected very readily, becoming more resistant as they mature. The infection is often lethal and the mortality rate can be $100 \%$ in fry. Some fish that survive an outbreak of IHN may become carriers of the virus, providing a reservoir of infection. In addition, infected juveniles shed IHN virus particles in the faeces, urine and external mucus.

Researchers at the WFRC are creating a set of molecular tools by cloning each of the viral genes and sequencing the entire genome. This information is stored in an IHN database. When an IHN virus epidemic occurs, our researchers use molecular genetic methods to characterize the specific virus type, and compare it with other known

IHNV types in our database.

Similar methods are used for other fish viruses and for epidemics of flu, SARS, and anthrax. Over 600 IHN virus samples from throughout the Pacific Northwest have been characterized to date.

\section{Studies have revealed that} infectious diseases can cause major losses in populations of freeranging fish and are significant factors in the ability of certain stocks to recover. Work has also served to highlight the critical role played by environmental conditions and other sources of stress in the ecology of fish diseases.

\section{Development of a novel vaccine for IHN}

IHN virus is a severe pathogen of salmon and trout that causes epidemics with 20$90 \%$ mortality. It is in the same virus family as the rabies virus. There is currently no commercially available vaccine for IHNV.
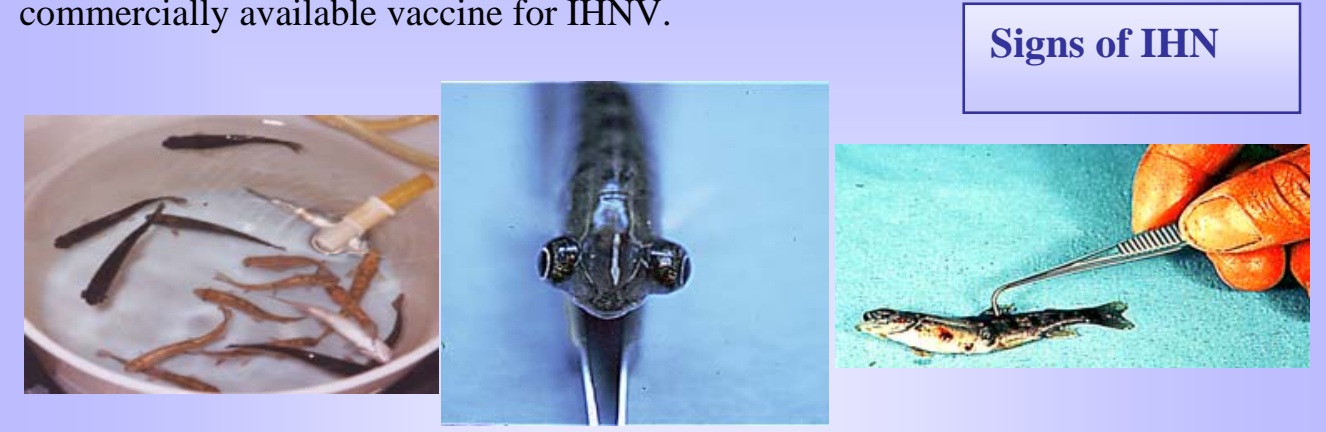

Here at WFRC we work with development of a novel DNA vaccine to protect fish against IHN virus. Left: The vaccine, pIHNV-wG, is a circular piece of DNA that carries the gene for the IHNV surface protein G. Right: The IHNV DNA vaccine will be tested against a placebo (control) vaccine to confirm protection against the disease.

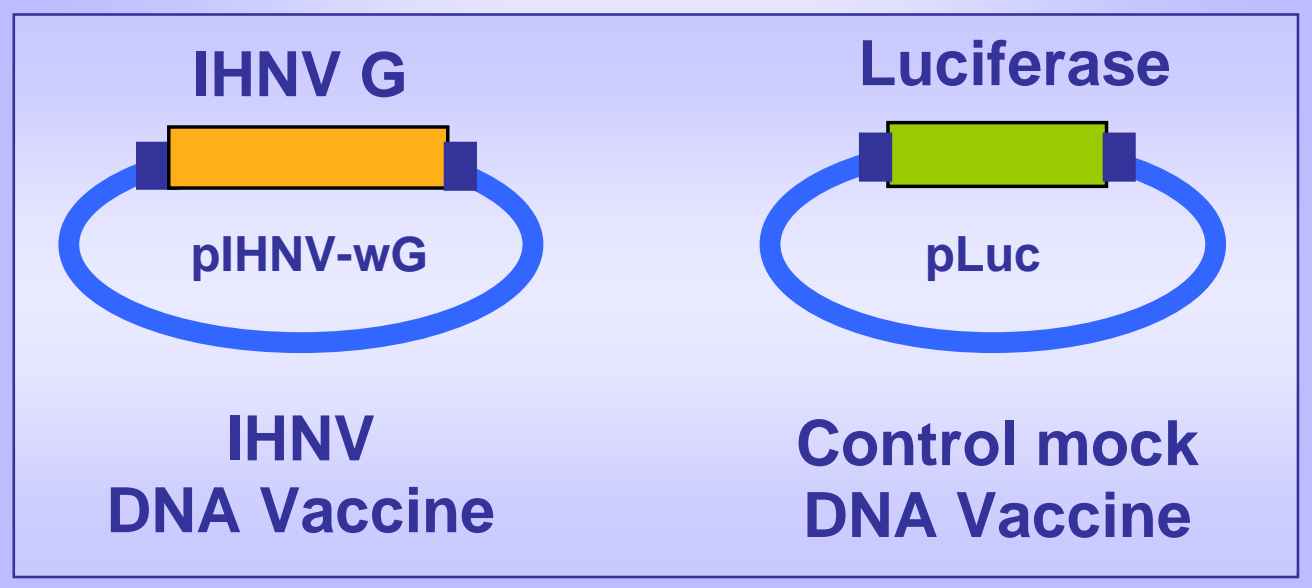

\section{Additional Reading}

Miller, K.M., J.R. Winton, A.D. Schulze, M.K. Purcell, and T.J. Ming. 2004. Major histocompatibility complex loci are associated with susceptibility of Atlantic salmon to infectious hematopoietic necrosis virus. Environ. Biol. Fishes 69: 307-316.

Kocan, R.M., P.K. Hershberger, and J. Winton. 2004.

Ichthyophoniasis: An Emerging

Disease of Chinook Salmon

(Oncorhynchus tshawytscha) in the Yukon River. J. Aquat. Anim. Health 16:58-72.

Anderson, E.D., H.M. Engelking, E.J. Emmenegger, and G. Kurath. 2000. Molecular epidemiology reveals emergence of a virulent infectious hematopoietic necrosis (IHN) virus strain in wild salmon and its transmission to hatchery fish. J. Aquat. Anim. Health 12:85-99.

Allen, B.M., E.P. Bergersen. 2002. Factors influencing the distribution of Myxobolus cerebralis, the causative agent of whirling disease, in the Cache la Poudre River, Colorado. Dis. Aquat. Org. 49:5160.

\section{A complete list of WFRC publications can be found on our website at:}

http://wfrc.usgs.gov/pubs/pubs.htm

For additional information, please contact:

Lyman Thorsteinson, Center Director U.S. Geological Survey Western Fisheries Research Center 6505 NE $65^{\text {th }}$ Street Seattle, WA 98115

Phone: (206-526-6282

FAX (206) 526-6654

http://wfrc.usgs.gov 